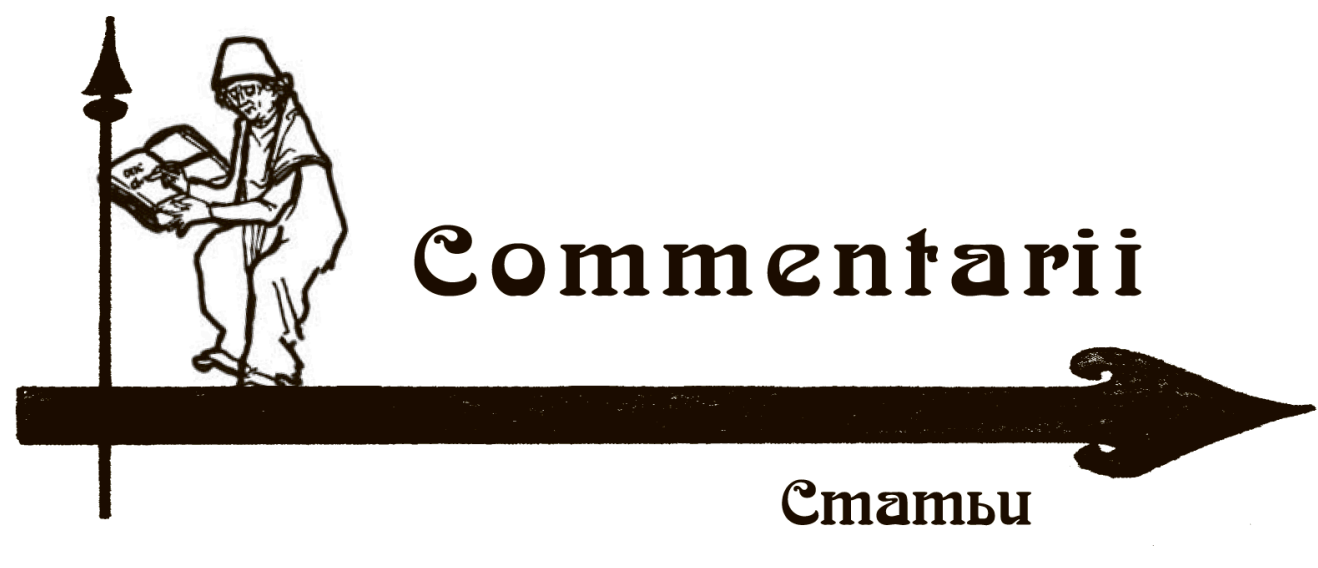

СЛАВЯНСКАЯ ИДЕНТИЧНОСТЬ В СРЕДНИЕ ВЕКА

УДК 94(367) Славяне; ББК 63.3(2)41; DOI 10.21638/11701/spbu19.2017.101

A. Mesiarkin

\title{
THE NAME OF THE SLAVS: ETYMOLOGY AND MEANING
}

A name is the first identification attribute of a barbarian group. This does not apply only to a term the group is referred to in written sources and which distinguishes the group cognitively from other groups. When taking into consideration an anthropological premise that ascribes a significant role within the group identity (or the group as such) to the complex of myths and symbols ${ }^{1}$, the actual name represents an essential point of the self-identification. Together with the second essential feature (psychologically interconnected with the first one) - a historical (theogonic, cosmogonic) myth, it shall be considered a basic element of the identity construction.

${ }^{1}$ Smith D. A. Myths and Memories of the Nation. Oxford, 1999. P. 13.

(C) A. Mesiarkin, 2017 
Once a new name is discovered on a map of the ancient and medieval knowledge, it might ipso facto represent ethnogenesis of the group and thus the very existence of that particular society. Its further occurrence and transformation in literature subsequently reflects motives of ancient and medieval ethnography and historiography. We believe that the name $\Sigma \kappa \lambda \alpha \beta \eta v o i$, Sclavini was originally a name of a single group and later on, thanks to various intellectual and ideological determinants, spread and referred to more groups — until it reached a semantical form we recognise even nowadays ${ }^{2}$. Traditionally, a chronological milestone distinguishing the «pre-historic» Slavs from those «historic» captured by historians ${ }^{3}$ had emerged once Procopius and Jordanes started reflecting a name of one of the groups of the Lower Danube barbaricum - $\Sigma \kappa \lambda \alpha \beta \eta v$ oí $^{4}$.

Naturally, an ethnographic brand «Veneti» holds the most significant position among the «older Slavic names» within the relevant literature ${ }^{5}$. We know that Venedi / Venethi / Vinidi are to be found across a wide European geographical context (from Bretagne to Paphlagonia in Asia Minor), thus they are not to be interconnected with the Slavs

${ }^{2}$ As Franc Miklošić wrote as early as in 1874: «Ich möchte ferner auf den namen der sprache der Slovaken: slovenský jazyk hinweisen, was wieder als grund für die angeführte ansicht nur jene gelten zu lassen geneigt sein werden, die mit mir der überzeugung sind, dass der name: slověne ursprünglich der name einzelnes slavischen stammes, nicht der ganzen slavischen volkes war» (Miklosich F. Altslovenische Formenlehre in Paradigmen mit Texten aus Glagolitischen Quellen. Wien, 1874. P. IV). Relevant criticism to be found for instance in: Otrębski J. Słowianie. Rozwiązanie odwiecznej zagadki ich nazw. Poznań, 1947. P. 25-27; Schramm G. Ein Damm bricht. Die römische Donaugrenze und die Invasionen des 5.-7. Jahrhunderts im Lichte von Namen und Wörter. München, 1997. P. 171-173.

${ }^{3}$ Šafárik P. J. Slowanské starožitnosti. Oddjl děgepisný. Praha, 1837. P. 39; Niederle L. Slovanské starožitnosti. D. 2. Sv. 1: Původ a počátky Slovanů jižních. Praha, 1906, P. 469; Pritsak O. The Slavs and the Avars // Gli Slavi occidentali e meridionali nell'alto medioevo. International conference in Spoleto 15.4.-21.4.1982. Spoleto, 1983. P. 366.

${ }^{4}$ In the same Greek form as in Procopius in an work of author commonly known as Caesarii sapientissimi viri: Dialogi Quatuor. Interrogatio CX // Sancti patris nostri Gregorii Theologi, vulgo Nazianzeni, archiepiscopi Constantinopolitani. Operae quae extant omnia (Patrologiae Grecae. T. 38). Turnholti, 1969. P. 985-986; Benedicty R. Prokopios' Berichte über die slavische Vorzeit. Beiträge zur historiographischen Methode des Prokopios von Kaisareia // Jahrbuch der Österreichischen Byzantinischen Gesselschaft. 1965. Vol. 14. Р. 61; Баришић Ф. Када и где су написали Псеудо-Цезаријеви Дијалози // ЗРВИ. 1952. Vol. 1. P. 45; Riedinger R. PseudoKaisarios: Überlieferungsgeschichte und Verfasserfrage. München, 1969. P. 272-273, 302-303.

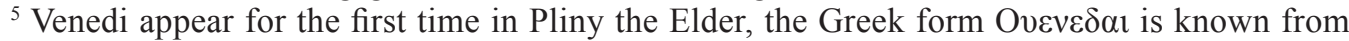
Ptolemy's Geography from the 2nd century, the Latin version comes from Tacitus - Wenethi. Pliny's Naturalis Historiae. Book 2. Ch. 170; Book 4. Ch. 13 and 96-97, and Geography. Book 3. Ch. 5. Part 1, 5, 7 and 8. - Claudius Ptolemy quoted from: Panzer B. Quellen zur slavischen Ethnogenese. Fakten, Mythen und Legenden. Heidelberg Publikationen zur Slavistik: A) Linguistische Reihe. Vol. 14. Frankfurt am Main, 2002. P. 15-19; P. Cornelius Tacitus. Germania / Ed. A. Lund. Heidelberg, 1988, the introductory study on P. 48; chapter 46 on P. 107. — Zbigniew Babik points to a reality of two existing names with th and $d$ as a possibility of gradual alternation of a German linguistic term via a Latin medium: Babik Z. Współnota językowa prasłowiańska // Przeszłość społeczna. Próba konceptualizacji / Ed. by S. Tabaczyński, A. Marciniak, D. Cyngot, A. Zalewska. Poznań, 2012. P. 843. - For Jordanes' motivation see, e. g.: Pritsak O. The Slavs and the Avars. P. 382-383. 
automatically ${ }^{6}$. We also have to take into consideration a mere historical fact that the Slavs never called themselves by this name ${ }^{7}$. A synonymic equation (Veneti - Slavs) which had given the ancient roots to the Slavs was authored by Jordanes ${ }^{8}$. However, under Jordanes' (or Cassiodorus') influence, we cannot project «Slavicism» (Slavic identity, «Slavicity» or «Slavinity») of the Veneti onto a situation in the Early Antiquity ${ }^{9}$. A similar method of a «geographically conditioned likening», emanation of a chronologically older unit, was

${ }^{6}$ Curta F. The Making of the Slavs. History and archaeology of the Lower Danube Region, c. 500-700. Cambridge, 2001. P. 41. - For an opposite stance, see: Gołab Z. Veneti / Venedi. The oldest name of the Slavs // Journal of Indo-European Studies. 1975. Vol. 3. P. 321-326; Schramm G. Venedi, Antes, Sclaveni, Sclavi. Frühe Sammelbezeichnungen für slawische Stämme und ihre geschichtlicher Hintergrund // Jahrbücher für Geschichte Osteuropas. 1995. Vol. 43. Nr 2. P. 161; Kolendo J. Wenetowie a Słowianie // Z Otchłani Wieków: Pismo poświęcone pradziejom Polski. 1985. Vol. 51. No. 3-4. P. 128.

7 Wenskus R. Stammesbildung und Verfassung. Die Werden der frühmittelalterlichen gentes. Köln, 1961. P. 233; Lysý M. Moravania, Mojmírovci a Franská ríša. Štúdie k etnogenéze, politickým inštitúciám a ústavnému zriadeniu na území Slovenska vo včasnom stredoveku. Bratislava, 2014. P. 45, note 107; Steinacher R. Wenden, Slawen, Vandalen. Eine frühmittelalterische pseudologische Gleichzetung und Ihre achwirkungen bis ins 18. Jahrhundert // Die Suche nach den Ursprüngen. Von der Bedeutung des frühen Mittelalters. Wien, 2004. P. 329-353.

${ }^{8}$ Iordanis. Getica. V.34-35; XXIII.119 // MGH: Auctores antiquissimi 5, 1 / Ed. Th. Mommsen. Berolini, 1882. P. 62-63, 88-89. - In addition, the treatise Romana does not mention the Veneti along the Antes and Sclaveni (here as Sclavini, not Sclaveni as in Getica) in the last catastrophic report: Iordanis. Romana, 388. P. 52; Jordanes. Gótské dějiny / Ř́mské dějiny / Ed. S. Doležal. Praha, 2012. P. 35; Labuda G. Fragmenty dziejów Słowiańszczyzny zachodniej, 1. Poznań, 1960. P. 37. - A connection Sclaveni-Venethi-Antes is to be understood as Jordanes' geographicalgenealogical tool. Jordanes' interpolation on numerous Veneti in a wide area on the Eastern Wisła pays tribute to the ancient geography. We know next to nothing concerning the Veneti at the times of Jordanes or Procopius. Procopius mentions Venetia meaning the actual area around Venice when talking about stationed Gothic units: Procopius. De bello gothico, I.11 // Corpus Scriptoriae Historiae Byzantinae. Bonnae, 1833. P. 2. Vol. 2. P. 59. — As Jordanes had known from his sources, a group called Venethi had been placed somewhere in Scythia by the ancient geography. A well-known, easily pronounceable name made the information transfer within remote barbarian groups easier. As a Goth, he might have known it was a Germanic-linguistic term used for all those «unfamiliar in the East»; this is an analogy to Walchi / Velchi for all those «unfamiliar in the West» of Germanic-linguistic groups: Schramm G. 1) Ein Damm bricht... P. 168; 2) Venedi, Antes, Sclaveni, Sclavi. P. 162; Pohl W. Die Germanen. München, 2000. P. 50.

${ }^{9}$ This is a similar moment as with a name Allemani, originally labelling only one of the Germanic-linguistic tribes, which has endured until nowadays and in French serves as a name for the present-day Germans, or in an extensive interpretation, for all the German-speaking people. However, as a gens, the Alamanni had never lived to experience the «Germanism» thus «Germanism» cannot be projected retrospectively onto them: Pohl W. Die Germanen. P. 10; Puschner U. Germanenideologie und völkische Weltanschauung // Zur Geschichte der Gleichung «germanisch-deutsch». Berlin; New York, 2004. P. 103-129. - A question of locating the Veneti (and of course, the issue of Veneti's Slavism) was particularly important for the dynamics of the topic of Slavic ethnogenesis in the Polish milieu: Labuda G. Udział Wenetów w etnogenezie Słowian // Etnogeneza i topogeneza Słowian. Warszawa; Poznań, 1980. P. 29-41; Kolendo J. Wenetowie a Słowianie. P. 23; Nalepa J. O pierwotnych siedzibach Słowian w świetle nowszych badań archeologicznych, lingwistycznych i historycznych I // SA. 2007. Vol. 48. P. 17; Pritsak O. 
applied by Theophylact Simocatta when he connected the Slavs with ancient Getae ${ }^{10}$. Due to a later «non-tradition» or rather a «non-naming» the Slavs as Getae, this identification did not raise many emotions or interpretations ${ }^{11}$. Another «naïve» etymology mentioned by Procopius, namely the etymology of the name Sporoi which should have been applied for both Antes and Sclaveni represents the weakest of all of these theories ${ }^{12}$.

As far as this topic is concerned, firstly we would like to draw the attention to a terminological and epistemological discrepancy that has been accompanying the whole issue of the Slavic ethnogenesis and identity. The name of one of the Jordanes' groups Sclaveni is in both translation and semantic meaning identical with the present term — the Slavs. Thus the thing is that although Jordanes mentions three and Procopius two barbarian groups (Antes, Sclaveni and Venethi), one of these groups covers terminologically remaining groups as well therefore in literature, we can encounter «the Slavic Antes and Venethi». Thus the Sclaveni are the Slavs as well as the Antes and Venethi falls into the same category ${ }^{13}$. The term Slavs serves for both «narrower» and «broader» semantic application ${ }^{14}$. When talking about the events of the $6^{\text {th }}$ century, we understand and use the term «Slav» as an equivalent to a (Latin) Sclaven.

The Slavs and the Avars. P. 367; Niederle L. Slovanské starožitnosti. P. 472; Curta F. Four questions for those who still believe in prehistoric Slavs and other fairytales // SHP. Ser. III. 2015. Vol. 42. P. 286-303.

${ }^{10}$ Theophylacti Simocattae. Historiae, VI. 6 / Ed. C. de Boor. Stuttgart, 1972. P. 232. — His identification with the Getae also influences the interpretation of an older report on "Getic riders» from 517 as one of the oldest reports on the Slavs: Curta F. The Making of the Slavs. P. 75. ${ }^{11}$ Ossoliński J. M. Wiadomości historyczno-krytyczne do dziejów literatury polskiey: O pisarzach polskich, także postronnych, którzy w Polscze albo o Polscze pisali, oraz o ich dziełach; z rozstrząśnieniem wzrostu i różnéy kolei ogólnego oświecenia, jako też szczególnych nauk w Narodzie Polskim. T. 1. Kraków, 1819. P. 120; Bielowski A. Wstęp krytyczny do dziejów Polski. Lwów, 1850. P. 435.

${ }^{12}$ Procopius. De bello gothico, III.14. P. 366. - Barford justifies Procopius' etymology by a Polish adjective of spory in the meaning of sizeable, of a significant number: Barford $P$. The Early Slavs. London, 2001. P. 36. - Margetić assesses similar attempts as explicitly counterproductive: Margetić L. Etnogeneza Slavena // Rad HAZU. 2005. Vol. 492. P. 128. — Sasinek wrote that Sclavini or Sclaveni had been a name of the Slavs as early as in mid-6th century. Earlier, they had been Sporoi which means sowers - peasants, which is subsequently confirmed by Theophylact and Patriarch Fotius who call them Getes according to Sasinek also meaning the peasants. See: Marsina R. F. V. Sasinek: Dejepis Slovákov (Ružomberok 1895) // Čo písal o našich dejinách Franko Sasinek / Ed. P. Mulík. Martin, 2015. P. 16.

${ }^{13}$ The area of all three groups is thus usually called «Slavic settlement area». See: Fusek G., Zábojník J. Príspevok do diskusie o počiatkoch slovanského osídlenia Slovenska // Slovenská archeológia. 2003. Vol. 51. No. 2. P. 328; Třětík D. Příchod prvních Slovanů do českých zemí v letech 510-535 // ČC̆H. 1996. Vol. 94. No. 2. P. 253. - Of course, we are aware of Procopius' link between the Antes and Slavs, his motivation is similar to Jordanes'.

${ }^{14}$ Such a chain of ideas created a base for Neoslavists and Panslavists as it speaks about this three-kinds group of the Slavs of the 6th century as an archetype of all the modern Slavic nations, see: Téra M. Slovanská identita v raném středoveku // Slovanství ve středoevropském prostoru. Iluze, deziluze a realita. Praha, 2004. P. 53. - Respectively, in different variations as for instance present-day Russians - historical Antes, present-day Polish — historical Veneti, etc. See: Schramm G. Venedi, Antes, Sclaveni, Sclavi. P. 163. - The most extreme form of this concept is to be found in a reflection of Jordanes' three groups divided into three Slavic language groups or into three Slavic archaeological cultures and shall be handled rather soberly. 
Those pieces of information that enable the construction of the pillars of a barbarian group ethnic identity after many centuries are of an internal origin - especially from stories of origo gentis, or come from external sources - Roman, or post-Roman intellectuals. The Goths or Lombards do not concentrate their belongingness to the group around «own language» in their origo gentis. It is Tacitus, Isidor of Sevilla, Hrabanus Maurus or Regino of Prüm who emphasise the language as an identification symbol of gentes ${ }^{15}$. The barbarian elite, the militarized Traditionskern with an opposite approach to education, certainly did not ascribe the language such a significant position ${ }^{16}$. The role of a single «exclusively barbarian language» at a creation of the Slavic identity of the Sclaveni and Antes is mostly a projection of the modern linguists and historians.

A role of the language as far as a group identity is concerned becomes more prominent at the reconstruction of the ethnic name of the Slavs. A proposition about Slověnin, a Slavic ethnic group (gens, tribe, nation) representative whose auto-definition links him with other Slavs via the language and speech as early as in the $6^{\text {th }}$ century, or even a centuries earlier, has its unshakable place in the scholar discourse ${ }^{17}$. Thanks to a parallel to a more-than-a-thousandyear existence of the Slavic language, the ethnonym has been perceived as a symbol of the ancient times which had proved and confirmed its durability ${ }^{18}$.

Once the name issue is being approached, it is actually an attractive, «language-motivated» etymology which attempts to reconstruct an auto-ethnonym of the Slavs directly from the base and an individual word - ${ }^{*}$ slovo ${ }^{19}$. Such a name thus emerges as a result of, as Šimon Ondruš called it, «natural law of the opposition», where «mute Germans» symbolised the rivaling party. In literature, this reconstruction appears regularly, as the Slovak linguist put it: «Because for the Proto-Slavs, the Germanic people were babbling, inarticulate and that

${ }^{15}$ Pohl $W$. Telling the difference. Sings of Ethnic Identity // Strategies of distinction. The Construction of ethnic identities, 300-800. Leiden; Boston; Köln, 1998. P. 22-27.

${ }^{16}$ Procopius. De bello gothico I.2. P. 14. - Procopius mentions that Theodoric had banned Gothic children from attending the school.

${ }^{17}$ Schachmatov A. A. Zu den ältesten slavisch-keltisch Beziehungen (Herrn Akademiker Th. Korsch gewidmet) // Archiv für slavische Philologie. 1911. Vol. 33. No. 1/2. P. 83. — Schachmatov rejects the Veneti having been the Slavs which is an important feature of his work. He considers them Celtic which is to be explained by a proximity of the Celtic and Slavic language. He also claims the name of the Veneti was transferred to the Slavs because they had originally been «neighbours» of the Germanic tribes - who in exchange, had used this name for all their neighbours in the east: Schramm G. Venedi, Antes, Sclaveni, Sclavi. P. 165; Homza M. Stredná Európa I. Na začiatku stredoveku. Bratislava, 2014. P. 32; Popowska-Taborska H. Utrwalone w języku ślady etnicznej wspólnoty Słowian // Z językowych dziejów Słowiańszczyny. Warszawa, 2004. P. 161; Tyszkiewicz L. Słowianie w historiografii antycznej do połowy VI wieku. Wrocław, 1990. P. 129; Pohl W. Ein Jahrtausend der Wanderungen, 500-1500 // Kontinuitäten und Brüche: Lebensformen - Alteingesessene - Zuwanderer von 500 bis 1500. Klagenfurt, 2010. P. 156. - Quite a contrary position in: Brückner A. Dzieje kultury polskiej. T. I. Od czasów przedhistorycznych do r. 1506. Kraków, 1930. P. 8, who states the Slavs are actually the mute one doe to Gothic slavan.

${ }^{18}$ Otrębski J. Słowianie... P. 6.

${ }^{19}$ Šafárik P. J. Dejiny slovanského jazyka a literatúry všetkých nárečí. Bratislava, 1953. P. 49, 59; Otrębski J. Słowianie... P. 36.

${ }^{20}$ Ondruš Š. Pôvod etnonyma Slovák, Slovan, Slověn a etnonyma Čech // Studia Academica Slovaca. Prednášky XI. letného seminára slovenského jazyka a kultúry. 1975. Vol. 4. P. 241: «Preto využili na pomenovanie seba samých z indoeurópčiny zdedené slová, resp. slovný základ ḱlew-: ḱlow-, po samizácii slew-: slow- v zmysle počujúci, rozumejúci, používajúci slová, oproti germánskemu brblaniu, nemote». 
is why they perceived themselves being a counterpart to the Germanic people as they were speaking clearly, using the words» ${ }^{20}$. Then Ondruš continues: «With a huge probability, we may assume that a primal collective name for the Slavs was Slovi, meaning those who listen, speak in an articulate manner and use words».

The second part of the ethnonym is (generally accepted) suffix *-ěninb/*-janinb (plural *-jane) which represents some sort of the «affinity», «close relationship» ${ }^{21}$. Slověn / Slovan (in a so-called non-productive form) would have been an appellative similar to bratěn / bratan which de facto confirms a thesis of the Slavs as those «linguistically» related $^{22}$. Among the Slavists, it was by no means less popular searching for a word base in a word sláva (glory) as an Adam Czarnocki's quotation attests ${ }^{23}$. In an attempt to come to a satisfactory etymology, attention has been focused on more «romantic» interpretations. There were some attempts to reconstruct the name as a derivation from the natural environment where the Slavs had been believed to have lived in literature. Slověne are those who should have lived in the area of mysterious Slova, a further unidentified location of Jan Peisker, or placed close to some island - Lithuanian salava of Leszek Moszyński²4. The base of names as Slavo, Slova, Slavje is supposed to indicate an Indo-European denominator *kleu- in a meaning of to flow ${ }^{25}$. However, a suitable geographical object has not been satisfyingly identified yet ${ }^{26}$. The most

${ }^{21}$ Schramm G. Venedi, Antes, Sclaveni, Sclavi. P. 183; Pritsak O. The Slavs and the Avars. P. 407; Popowska-Taborska H. Utrwalone w języku ślady etnicznej wspólnoty Słowian. P. 161; Sławski F. Słowianie // SSS. Vol. 5: S-Ś. Wrocław; Warszawa; Kraków; Gdańsk, 1975. P. 274.

${ }^{22}$ Moszyński L. Czy Słowianie to rzeczywiście nomen originis? // Z polskich studiów slawistycznych. Ser. 5. Językoznawstwo. Prace na VIII. międzynarodowy kongres slawistów w Zagrebiu 1978. Warszawa, 1978. P. 499, 507.

${ }^{23}$ «In common law and customs - there was their bond and unity. That was the root of honour, I mean, from there they could be covered with a crown and name of Glory (sławy)» (Surowiecki W. Z. D. Chodakowskiego O Słowiańsczyznie przed chrześciaństwem i W. Surowieckiego zdanie o pismie témźe $z$ dodaniem krótkiej wiadomości o Chodakowskim i korrespondencyi jego. Kraków, 1835. P. 9). Or in case of Slovak Ján Kollár, see: Podolan P. Sláwa Bohyně a původ gména Slaůw čili Slawjanůw... Jána Kollára // Historia nova. 2013. Vol. 6. P. 82-93.

${ }^{24}$ Peisker J. The expansion of the Slavs // The Cambridge Medieval History. Vol. 2. Cambridge, 1914. P. 421. - He also searches for a support of a proposition of the Slav (the one who speaks and understands) - Nemec/German (nemý/mute, thus the one who does not understand) in socalled Nestor's account on a tribe of Jugrii which is «foreign» — therefore not able to speak in: Peisker J. Die älteren Beziehungen der Slawen zu Turkotataren und Germanen und ihre sozialgeschichtliche Bedeutung. Stuttgart, 1905. P. 98; Moszyński L. Czy Słowianie to rzeczywiście nomen originis? P. 499. For an overview of the locations relevant at the times of World War Two see: Otrębski J. Słowianie... P. 40-42; Rospond S. Struktura pierwotnych etnonimów słowiańskich // Rocznik slawistyczny. 1966. Vol. 26. No. 1. P. 29-31.

${ }^{25}$ As *cleu in: Kučera M. Slovenské dejiny I. Od príchodu Slovanov do roku 1526. Prešov, 2008. P. 49; Stawski F. Słowianie // SSS. Vol. 5. P. 274. - A dictionary also states less appealing connotations as for instance English slow, Gothic slavan (probably coming from Aleksander Brückner) for being silent, for similar reference see: Moszyński L. Czy Słowianie to rzeczywiście nomen originis? P. 499.

${ }^{26}$ See: Otrębski J. Słowianie... P. 40-42. - However, there is a thesis concerning the river Zala in the present-day Hungary. An interesting reflection, presented in this text as a historical argument is that «neighbouring» regions of the Zala region are Slavonia and Slovenia, thus the linguistic groups in its proximity have called themselves Slavs and later on, Slovaks and Slovenians: Bačić J. The Slav: Origin and the meaning of the ethnonym // Slovene Studies. 1987. Vol. 9. No. 1/2. P. 38. 
attractive of these theories is deriving from one of the names for the Dnieper (though preserved as an epitheton ornans not earlier than in the $17^{\text {th }}$ century!) Slavuta, *Slovąta, or *Slaventa ${ }^{27}$. A base word *slov- is labelled by Jan Otrębski a stem of a reflexive pronoun (originally *slob-, documented in Gothic silba, or as a similar base for Celtic *selv-), which would mean the Slavs were «their own people / their people themselves» ${ }^{28}$. Linguists or historians working with linguistic facts built the auto-ethnonym of the Slavs a priori on a linguistic base - on *slovo (a word), which logically confirmed that a personal substrate that had created the ethnonym had done so on the basis of the Slavic linguistic equipment ${ }^{29}$. We do not presume that a group that had already established its representative «brand» - a name; placed in its identity a rational and conscious realization that they were using their own special «Slavic language». Such a motive would be quite unique as far as the ancient and early medieval barbaricum is concerned! $!^{30}$ Thus currently, we tend to reject a language as an identifying factor which helps creating the very base of the identity, represented by the auto-ethnonym of a group in case of the Slavs. From a merely technical point of view: such an «attribute» would not have delimited the Slavs - or Sclaveni even from their closest neighbours, the Antes — as Procopius writes they used the same barbarian language.

Therefore from August Schlözer onwards, it has been accepted that the Greek form Sklavenoi ( $\Sigma \kappa \lambda \alpha \beta \eta v o i ́)$ is derived from an originally Slavic form of Slověne (or Sloviene, alternatively Sloviane) $)^{31}$. The authors generally agree in this respect ${ }^{32}$. Wawrzyniec Surowiecki wrote that the Greeks (Greek-speaking) were inserting a consonant $\mathrm{k}$ between s and 1 in order to keep a diphthong Sl (thus a typical consonant cluster Skl) - otherwise they would not have

${ }^{27}$ Schramm G. Venedi, Antes, Sclaveni, Sclavi. P. 184. - The reasoning goes as follows: centuries later, groups or tribes were called according to the rivers. Even before Schramm, it had been Kazimierz Moszyński writing about a connection with the river Dnieper. He pointed out that a couple of Dnieper's Pripjat's or Don's tributaries wield the same base word *Slova, alebo *Slava, here explained as a «clear», «limpid» river (Moszyński K. Pierwotny zasiąg języka prasłowiańskiego. Wrocław; Kraków, 1957. P. 142).

${ }^{28}$ Havlík claims that Ptolemy had already incorrectly recorded Slavenoi / Sklavenoi under the term of Souobenoi (Havlik L. Osídlení Balkánu Slovany a byzantská historiografie // Studia Balkanica Bohemoslovaca. Brno, 1970. P. 50). This faulty transcription would have had, according to Otrębski, a philological base (Otrębski J. Słowianie... P. 54-56, 59).

${ }^{29}$ To be more precise, from a language which was labelled Slavic only centuries later. See: Otrębski J. Słowianie... P. 26; Schramm G. Venedi, Antes, Sclaveni, Sclavi. P. 165; Havlik L. Počátky slovanského vědomí // Slovanství v národním životě Čechů a Slováků. Praha, 1968. P. 19. The Slavic language appears for the first time at the liturgy in St. Peter's temple after the arrival to Rome, recorded in the Life of Saint Constantine (Žitije Konstantina), chapter XVII (MMFH. Vol. II. 1967. P. 111). Slavic scripture is being admired by Kocel' (chapter XV), the same applies for Pope Hadrian (chapter XVII) (MMFH. Vol. II. P. 105, 110).

30 Critically and curtly: Wenskus R. Stammesbildung und Verfassung. P. 97; Otrębski J. Słowianie... P. 38.

${ }^{31}$ Schlözer A. L. Nestor Kiovensis 1056-1114: Russische Annalen in ihrer slavonischen GrundSprache. Göttingen, 1802. P. 75.

${ }^{32}$ Among them for instance: Moszyński L. Czy Słowianie to rzeczywiście nomen originis? P. 502; Popowska-Taborska H. Utrwalone w języku ślady etnicznej wspólnoty Słowian. P. 161; Babik Z. Współnota językowa prasłowiańska. P. 842; Moszyński K. Pierwotny zasięg języka prasłowiańskiego. P. 141; Barford P. The Early Slavs. P. 29; Rospond S. Struktura pierwotnych etnonimów słowiańskich. P. 23. 
been able to pronounce $\mathrm{it}^{33}$. Concepts of originally non-Slavic stem of the ethnonym of the Slavs appear in the scholar discourse rather marginally. Omeljan Pritsak, later followed by Lujo Margetić suggested deriving the name of the Slavs from Turkic saqla-, a verb which can be translated as «to guard» or «to supervise» ${ }^{34}$. Pritsak derived a name of the Saqlabi, Sqlawi from (proto?) Turkic *saqla-gu, which he subsequently developed in a proto-Bulgarian forms of * saqla-w and then ${ }^{*}$ sqlaw- ${ }^{35}$.

A theory authored by Cracowian linguist Zbigniew Babik reconstructs an ethnonym which could have reflected an identity of the barbarian retinue. Babik considers a singular form ended with *-janin $\mathrm{b}$ as well as a plural form ended with *-jane secondarily derived (from the original *Slověni a *Slověn $\mathrm{b}$ ); on the other hand, he rejects the theory of deriving the ethnonym from *slovo as unconvincing, or rather inconsistent which is a proposition difficult to argue with ${ }^{36}$. In addition, Babik is quite right to emphasise that *slovo did not possess in the oldest preserved version of the Slavic language the same meaning as it has now (slovo, meaning a word; reč, meaning speech $)^{37}$, which undermines original logics behind a supposed construction of this auto-ethnonym. As the most probable option, Babik suggests the derivation of the name of the Slavs from a verb *sluti slovą, which means «to be famous», «to enjoy the glory» ${ }^{38}$. Such a derivation should originally have labelled those who «enjoy the glory», that means a group of warriors - then it would have served as a very apt name. Subsequently, this name was

${ }^{33}$ Surowiecki $W$. Śledzenie początku narodów słowiańskich. Wrocław; Warszawa; Kraków, 1964. P. 392; Otrębski J. Słowianie... P. 10. - Both hereby quoted authors present an example of the river Wisła mentioned by Jordanes, in a form of Viscla, Otrębski also Visculus by Pliny.

${ }^{34}$ Margetić L. Etnogeneza Slavena. P. 91, 137; Pritsak O. The Slavs and the Avars. P. 406. Pritsak and Margetić add a characteristics of a special type of auxiliary military troops of nomadic tribes (referring to the oldest sources by Jordanes and Procopius - Proto-Bulgarians) to the ethnonym based on a non-Slavic origin.

${ }^{35}$ The linguistic term shall find its confirmation in the language of the Bulgarians from the Volga region and Kipchaks: Pritsak O. The Slavs and the Avars. P. 406-411. - For a polemics with conclusions of the ethnonym etymology see: Pohl W. Die Awaren: Ein Steppenvolk in Mitteleuropa 567-822 n. Chr. München, 1988. P. 88, 366, note 3; Profantová N. Kultura s keramikou pražského typu a problém šíření slavinity do střední Evropy. K článku Florina Curty // Archeologické rozhledy. 2009. Vol. 61. P. 303.

${ }^{36}$ Actually, such a reconstruction (from a base word *slovo) does not appear in literature, only its natural confirmation as an attractive etymology occurs again and again, compare: Rospond $S$. Struktura pierwotnych etnonimów słowiańskich. P. 23; Babik Z. Współnota językowa prasłowiańska. P. 842. An (surprisingly) opposite evolution (from Slověnin to Sloven) is promoted by Mulik P. Použivanie klúčových termínov k počiatkom slovenských dejín // Etnogenéza Slovákov. Kto sme a aké je naše meno. Martin, 2011. P. 41 (based on: Stanislav J. Slovienin — Slovan — Slovák — Tót // Náš národ. 1944. No. 1. P. 25). Schramm points to the same suffix in case of a form «Roman» — gradually derived from rimb, and further on rimljěnin $\mathrm{b} / \operatorname{rimljanin} \mathrm{b}$, although these forms appear only centuries later (Schramm G. Ein Damm bricht... P. 145).

${ }^{37}$ See: Otrębski J. Słowianie... P. 37, who points out that the oldest form looked different *sloves-, which is confirmed by an Old Russian adjective form sloves-nyj (Babik Z. Współnota językowa prasłowiańska. P. 842). Similarly, it emphasises that it is not possible to reconstruct the name on the basis of a verb *sloviti, which cannot be traced back in this chronological layer either. ${ }^{38}$ This option is mentioned (together with a reconstruction) by Králik L'. Stručný etymologický slovník slovenčiny. Bratislava, 2015. P. 540. Marginally also by Otrębski J. Słowianie... P. 37; Babik Z. Współnota językowa prasłowiańska. P. 842. 
applied to a greater society and further on, via denominations in Greek and Latin, became an umbrella term for a conglomerate of groups - differing from other groups by designed ethnographic categories ${ }^{39}$.

Thus the name of originally a single group of the barbarians, which could be related to a language perceived by the Romans as a foreign - later on a means of communication applied in the Avar Khaganate as well as communities on its borders — spread slowly amongst those speaking that particular language ${ }^{40}$. Later etymology and semantics of the name of the Slavs was conditioned by a fact that the Slavs, originally a barbarian gens on the borders of the Roman Empire, had become a name for all the users of any form of relevant languages and dialects and a widespread ethnographic brand in the East Central Europe. In Frankish or Byzantine sources, there are accounts of people who had been given names ending with a suffix - slav $^{41}$, there are geographical entities named as Sclavonia, Sklavinia which were understood as the «land of the Slavs» ${ }^{42}$. The name of the Slavs was permanently embedded in both consciousness and knowledge of medieval intellectuals to such an extent that the first concepts of the history of the Slavs emerged at that time ${ }^{43}$. The most successful historical,

${ }^{39}$ Simultaneously with some metamorphoses of the very language form into a shorter Sclavi, Sklavoi in: Krahwinkler H. Augewählte Slaven-Ethnonyme und ihre historische Deutung // Slovenija in sosednje dežele med antiko in karolinško dobo. Začetki slovenske etnogeneze / Ed. R. Bratož. Ljubljana, 2000. P. 403-404; Otrębski J. Słowianie... P. 11-13, 69-80; Schramm G. Venedi, Antes, Sclaveni, Sclavi. P. 188-194.

${ }^{40}$ Dzino D. Becoming Slav, Becoming Croat. Identity transformations in post-Roman and early medieval Dalmatia. Leiden; Boston, 2010. P. 165, 216; Schramm G. Venedi, Antes, Sclaveni, Sclavi. P. 188; Curta F. The Making of the Slavs. P. 345; Barford P. The Early Slavs. P. 17. - See a contradicting stance: Babik Z. Współnota językowa prasłowiańska. P. 848-849.

${ }^{41}$ The first known Slav with the sufix -slav is Višeslav, the first chronologically known Serbian ruler mentioned in Constantine Porphyrogenitus' treatise De administrando imperio in chapter XXXII: Constantine Porphyrogenitus. De administrando imperio / Greek text ed. by Gy. Moravcsik; engl. transl. by R. J. H. Jenkins. Washington, 1967. P. 155. See: Dzino D. Becoming Slav, becoming Croat... P. 187; Živkovič T. De conversione Croatorum et Serborum. A lost source. Belgrade, 2012. P. 55.

${ }^{42}$ Theophylacti Simocattae. Historiae, VIII. 5. P. 293; Theophanis. Chronographia. Vol. 1. Lipsae: B. G. Teubner, 1873. P. 486; Curta F. 1) Sclaviniai and ethnic adjectives: A clarification // Byzantion Nea Hellás. 2011. Vol. 30. P. 81; 2) Theophylact Simocatta revisited. A response to Andreas Gkoutzioukostas // Byzantion Nea Hellás. 2016. Vol. 35. P. 195-209. — In a large extent see: Malinovská N. 1) Geographical concepts of Sclavinia in historical Sources from the Sixth to the Fourteenth Century with an Emphasis on the Moravian-Pannonian and South Slavic Traditions // Slovakia and Croatia. Historical parallels and connections (until 1780) / Ed. by M. Homza, J. Lukačka, N. Budak, V. Kucharská, S. Kuzmová, A. Mesiarkin. Bratislava; Zagreb, 2013. P. 60-65; 2) Povest' vremennych let a jej koncepcia Slovienskoj zemli // Štúdie k jubileu Pavla Jozefa Šafárika. Historia nova. Bratislava, 2011. Vol. 2. No. 1. P. 12-20; 3) Vývoj chápania geografického termínu Sklavínia v historických prameňoch 6.-14. storočia // HZ. 2008. No. 1. P. $124-143$.

${ }^{43}$ See the so-called Bavarian Geograph: Descriptio civitatum ad septentrionalem plagam Danubii (t. zv. Bavorský geograf). Praha, 1956. For dating and more see: Łowmiański H. O pochodzeniu Geografa bawarskiego // Roczniki historyczne. 1955. Vol. 20. P. 10-15; Zakrzewski S. Opis grodów i terytoryów z północnej strony Dunaju czyli t. z. Geograf bawarski. Lwów, 1917. P. 9-11. Chronologically close is text of al-Masúdi: Al-Masúdi. Správa o Slovanoch, o ich sídlach, o ich vládcoch a kmeňoch // Arabské správy o Slovanoch (9.-12. storočie). Bratislava, 1999. 
ideological as well as spiritual concept was authored by Constantine the Philosopher. He interconnected the etymology «conditioned by the language» with the symbolic of the Christianity in an introduction to a Slavic translation of the Gospel Book (Aprakos), called Proglas. The name of this society, derived from a (Slavic linguistic) word base *slovo and the naming of the Slavs as «People of the Word» is an intellectual-religious axis of the concept of the second half of th $9^{\text {th }}$ century. The same applies to later texts, celebrating Byzantine mission in Moravia and Pannonia ${ }^{44}$. The Slavists have kept trying to trace this etymology back to the $5^{\text {th }}$ and $6^{\text {th }}$ century. Thus codified (as well as sacred), the Slavic language represented an strong tool in an self-identification with a (much older) linguistic reality present on European area(s).

However, these are phenomena that only follow a historical fact of creation and existence of the name of the Slavs. The retinue that had planned and organized the raids to the right bank of the river Danube in the first decades of the 6th century did not «suffer» from similar intellectual delicacy. When accepting a widespread opinion of a Slavic linguistic base of the ethnonym, we must realize that this fact was no hindrance for «other» members of Slavic Traditionskern, for sure the Antes, Gepides or Lombards. Quite the contrary, the name celebrating the victors was very apt for a heterogeneous group.

\section{Данные о статье}

Автор: Месяркин, Адам - доктор истории, ассистент, Институт социальной медицины и медицинской этики, Медицинский факультет, Университет им. Я. А. Коменского, Братислава, Словакия, adam.mesiarkin@fmed.uniba.sk

Заголовок: Имя славян: этимология и значение

Резюме: Название является основным конституирующим элементом и важнейшим идентификационным признаком варварской общности. Фиксация в VI в. в трудах Прокопия Кесарийского и Иордана названия $\Sigma \kappa \lambda \alpha \beta \eta v o i ́$ в качестве обозначения одной из групп задунайского барбарикума является тем хронологическим рубежом, который отделяет славян доисторического времени от славян, зафиксированных историками. Долгое время в историографии считалось, что славяне как «народ» или «культурная общность» существовали задолго до VI в., скрываясь в источниках под другими именами. Из этих имен самым важным считалось название венетов / венедов. Однако славяне стали венетами, а венеты славянами лишь благодаря Иордану. Автор статьи склоняется к мнению, что на-

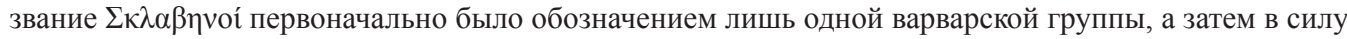
различных интеллектуальных и идеологических факторов стало переноситься на другие общности, пока не обрело то значение, в котором оно понимается сегодня. Лингвистами, а также историками, опиравшимися на лингвистические факты, самоназвание славян было априорно интерпретировано как основывающееся на общности языка - на понятии «слово», из чего следовало, что данная этническая общность возникла на основе языковой общности. Тезис о словенах как «ясно говорящих», то есть о существовании этнической группы, представители которой уже в VI в. или даже еще раньше самоопределялись через общий язык, до сих пор занимает прочные позиции в научной литературе. Однако, на взгляд автора статьи, картина, согласно которой к появлению группового названия «славяне» привело рациональное осознание членами данной группы того, что они используют уникальный «славянский язык», не является убедительной. Выведение названия общности славян от (славянской языковой) основы *slovo и восприятие славян как «народа слова» возникли гораздо позже: языковое прочтение этнонима «славяне» является стержнем интеллектуально-религиозной концепции, которая

${ }^{44}$ Konštantín Filozof. Proglas / Ed. by A. Fischerová; transl. by E. Pauliny. Bratislava, 2004. P. 17; Otrębski J. Słowianie... P. 33; Havlik L. Počátky slovanského vědomí. P. 18; Katičić R. Die Ethnogenesen in Avaria // Typen der Ethnogenese unter besonderer Berücksichtung der Bayern. Vol. 1 / Ed. H. Wolfram, W. Pohl. Wien, 1990. P. 126; Homza M. Niekol'ko poznámok k básni Proglas // Symboly a mýty národov v stredoveku a včasnom novoveku. Bratislava, 2014. P. 13-24. 
оформилась во второй половине IX в. в связи с миссией свв. Кирилла и Мефодия в Моравии и Паннонии. По этой причине автор статьи считает первоначальной этимологией названия «славяне» ту этимологию, которую разработал польский лингвист Збигнев Бабик. На взгляд автора, этимология 3. Бабика более адекватно отражает реальность варварского мира раннего Средневековья.

Ключевые слова: этноним «славяне», славянская идентичность, славянский этногенез, Sclavi, slovene

Литература, использованная в статье

Баришић, Фрањо. Када и где су написали Псеудо-Цезаријеви Дијалози // Зборник радова Византолошког института. 1952. Књ. 1. С. 29-51.

Babik, Zbigniew. Współnota językowa prasłowiańska // Przeszłość społeczna. Próba konceptualizacji / Red. Stanisław Tabaczyński, Arkadiusz Marciniak, Dorota Cyngot, Anna Zalewska. Poznań: Wydawnictwo Poznańskie, 2012. S. 838-851.

Bačić, Jakov. The Slav: Origin and the meaning of the ethnonym // Slovene Studies. 1987. Vol. 9. No. 1/2. P. 33-41.

Barford, Paul. The Early Slavs. London: British Museum Press, 2001. 416 p.

Benedicty, Robert. Prokopios' Berichte über die slavische Vorzeit. Beiträge zur historiographischen Methode des Prokopios von Kaisareia // Jahrbuch der Österreichischen Byzantinischen Gesselschaft. 1965. Bd 14. S. 61.

Bielowski, August. Wstęp krytyczny do dziejów Polski. Lwów: Nakł. Włodzimirza Hr. Dzieduszyckiego, 1850. $542 \mathrm{~s}$.

Brückner, Aleksander. Dzieje kultury polskiej. T. 1: Od czasów przedhistorycznych do r. 1506. Kraków: Nakładem Krakowskiej Spółki Wydawniczej, 1930. 58 s.

Curta, Florin. The Making of the Slavs. History and Archaeology of the Lower of the Lower Danube Region, c. 500-700. Cambridge: Cambridge University Press, 2001. 436 p.

Curta, Florin. Sclaviniai and ethnic adjectives: A clarification // Byzantion Nea Hellás. 2011. Vol. 30. P. 77-89.

Curta, Florin. Theophylact Simocatta revisited. A response to Andreas Gkoutzioukostas // Byzantion Nea Hellás. 2016. Vol. 35. P. 195-209.

Dzino, Danijel. Becoming Slav, Becoming Croat. Identity transformations in Post-Roman and early medieval Dalmatia. Leiden; Boston: Brill Academic Publishers, 2010. 271 p.

Fusek, Gabriel; Zábojník, Jozef. Príspevok do diskusie o počiatkoch slovanského osídlenia Slovenska // Slovenská archeológia. 2003. Roč. 51. Č. 2. S. 319-340.

Gołab, Zbigniew. Veneti / Venedi. The oldest name of the Slavs // Journal of Indo-European Studies. 1975. Vol. 3. P. 321-326.

Havlik, Lubomír. Osídlení Balkánu Slovany a byzantská historiografie // Studia Balcanica Bohemoslovaca / Red. Richard Pražák, Ivan Dorovský. Brno: Universita J. E. Purkyně, 1970. S. 48-58.

Havlik, Lubomír. Počátky slovanského vědomí // Slovanství v národním životě Čechů a Slováků / Red. Vladislav Št’astný. Praha: Melantrich, 1968. S. 17-23.

Homza, Martin. Stredná Európa I. Na začiatku stredoveku. Bratislava: Univerzita Komenského, 2014. 313 s. Homza, Martin. Niekol'ko poznámok k básni Proglas // Symboly a mýty národov v stredoveku a včasnom novoveku / Red. Martin Homza, Adam Mesiarkin. Bratislava: Vydavatel'stvo Univerzity Komenského, 2014. S. 13-24.

Katičić, Radoslav. Die Ethnogenesen in Avaria // Typen der Ethnogenese unter besonderer Berücksichtung der Bayern. Bd 1 / Hrsg. von Herwig Wolfram und Walter Pohl. Wien: Verlag der Österreichischen Akademie der Wissenschaften, 1990. S. 125-128.

Kolendo, Jerzy. Wenetowie a Słowianie // Z Otchłani Wieków: Pismo poświęcone pradziejom Polski. 1985. T. 51. Nr 3-4. S. 125-130.

Krahwinkler, Harald. Augewählte Slaven-Ethnonyme und ihre historische Deutung // Slovenija in sosednje dežele med antiko in karolinško dobo. Začetki slovenske etnogeneze / Ed. Rajko Bratož. Ljubljana: Narodni muzej Slovenje, 2000. S. 403-423.

Králik, Lubor. Stručný etymologický slovník slovenčiny. Bratislava: VEDA, 2015. 704 s.

Kučera, Matúšs. Slovenské dejiny I. Od príchodu Slovanov do roku 1526. Prešov: Vydavatel'stvo Michala Vaška, 2008. $358 \mathrm{~s}$.

Labuda, Gerard. Fragmenty dziejów Słowiańszczyzny zachodniej, 1. Poznań: Wydawnictwo Poznańskie, 1960. $312 \mathrm{~s}$. 
Labuda, Gerard. Udział Wenetów w etnogenezie Słowian // Etnogeneza i topogeneza Słowian: Materiały z konferencji naukowej zorganizowanej przez Komisję Slawistyczną przy Oddziale PAN w Poznaniu w dniach 8-9 XII 1978 / Red. Irena Kwilecka. Warszawa; Poznań: Państwowe Wydawnictwo Naukowe, 1980. S. 29-41.

Lysý, Miroslav. Moravania, Mojmírovci a Franská ríša. Štúdie k etnogenéze, politickým inštitúciám a ústavnému zriadeniu na území Slovenska vo včasnom stredoveku. Bratislava: Atticum, 2014. 373 s.

Malinovská, Nora. Geographical concepts of Sclavinia in historical sources from the sixth to the fourteenth century, with an emphasis on the Moravian-Pannonian and South Slavic tradition // Slovakia and Croatia. Historical parallels and connections (until 1780) / Ed. by Martin Homza, Ján Lukačka, Neven Budak, Veronika Kucharská, Stanislava Kuzmová, Adam Mesiarkin. Bratislava; Zagreb: Department of Slovak history, Faculty of Philosophy of the Comenius University, Bratislava; Faculty of Philosophy of Zagreb University, 2013. P. 60-65.

Margetić, Lujo. Etnogeneza Slavena // Rad HAZU. 2005. Knj. 492. S. 91-143.

Marsina, Richard. F. V. Sasinek: Dejepis Slovákov (Ružomberok 1895) // Čo písal o našich dejinách Franko Sasinek / Red. Peter Mulík. Martin: Matica Slovenská, 2015. S. 11-39.

Miklosich, Franz. Altslovenische Formenlehre in Paradigme. Texten aus Glagolitischen Quellen. Wien: Wilhelm Braumüller. $96 \mathrm{~s}$.

Moszyński, Kazimierz. Pierwotny zasiąg języka prasłowiańskiego. Wrocław; Kraków: Zakład Narodowy im. Ossolińskich, 1957. $332 \mathrm{~s}$.

Moszyński, Leszek. Czy Słowianie to rzeczywiście nomen originis? // Z polskich studiów slawistycznych.

Seria 5: Językoznawstwo. Prace na VIII. międzynarodowy kongres slawistów w Zagrebiu 1978. Warszawa: Państwowe Wydawnictwo Naukowe, 1978. S. 497-507.

Mulik, Peter. Používanie kl'účových termínov k počiatkom slovenských dejín // Etnogenéza Slovákov. Kto sme a aké je naše meno. Martin: Matica Slovenská, 2011. S. 39-53.

Nalepa, Jerzy. O pierwotnych siedzibach Słowian w świetle nowszych badań archeologicznych, lingwistycznych i historycznych I // Slavia Antiqua. 2007. T. 48. S. 11-46.

Niederle, Lubor. Slovanské starožitnosti. Díl 2. Svazek 1. Původ a počátky Slovanů jižních. Praha: Nákladem Bursíka a Kohouta, 1906. 547 s.

Ondruš, Šimon. Pôvod etnonyma Slovák, Slovan, Slověn a etnonyma Čech // Studia Academica Slovaca. Prednášky XI. letného seminára slovenského jazyka a kultúry. 1975. T. 4. S. 223-241.

Ossoliński, Józef Maksymilian. Wiadomości historyczno-krytyczne do dziejów literatury polskiey: O pisarzach polskich, także postronnych, którzy w Polscze albo o Polscze pisali, oraz o ich dziełach; z rozstrząśnieniem wzrostu i różnéy kolei ogólnego oświecenia, jako też szczególnych nauk w Narodzie Polskim. T. 1. Kraków: s. n., 1819. 507 s.

Otrębski, Jan. Słowianie. Rozwiązanie odwiecznej zagadki ich nazw. Poznań: Księgarnia ziem zachodnich, 1947. $191 \mathrm{~s}$.

Panzer, Baldur. Quellen zur slavischen Ethnogenese. Fakten, Mythen und Legenden (Originaltexte mit Übersetzungen, Erläuterungen und Kommentaren). Heidelberg Publikationen zur Slavistik: A. Linguistische Reihe. Bd 14. Frankfurt am Main: Peter Lang, 2002. S. 15-19.

Peisker, Jan. Die älteren Beziehungen der Slawen zu Turkotataren und Germanen und ihre sozialgeschichtliche Bedeutung. Stuttgart: Verlag von W. Kohlhammer, 1905. 243 s.

Peisker, Jan. The expansion of the Slavs // The Cambridge Medieval History. 1914. Vol. 2. Cambridge: Cambridge University Press, 1914. P. 418-458.

Podolan, Peter. Sláwa Bohyně a původ gména Slaůw čili Slawjanůw... Jána Kollára // Historia nova. Štúdie o dejinách. Vol. 6. Bratislava: Stimul, 2013. S. 82-93.

Pohl, Walter. Die Awaren: Ein Steppenvolk in Mitteleuropa 567-822 n. Chr. München: Beck, 1988. $553 \mathrm{~s}$.

Pohl, Walter. Die Germanen. München: Oldenbourg, 2000. 156 s.

Pohl, Walter. Ein Jahrtausend der Wanderungen, 500-1500 // Kontinuitäten und Brüche: Lebensformen Alteingesessene - Zuwanderer von 500 bis 1500 / Hrsg. von Karl Kaser. Klagenfurt: Wieser, 2010. S. 150-159.

Pohl, Walter. Telling the difference. Sings of ethnic identity // Strategies of distinction. The construction of ethnic identities, 300-800 / Ed. by Walter Pohl and Helmut Reimitz. Leiden; Boston; Köln: Brill Academic Publishers, 1998. P. 17-71. 
Popowska-Taborska, Hanna. Utrwalone w języku ślady etnicznej wspólnoty Słowian // Z językowych dziejów Słowiańszczyny. Warszawa: Slawistyczny Ośrodek Wydawniczy, 2004. S. 161-166.

Pritsak, Omeljan. The Slavs and the Avars // Settimane di studio del centro italiano di studi sull'alto medioevo. Vol. XXX: Gli Slavi occidentali e meridionali nell'alto medioevo. Spoleto, 1983. P. 353-435.

Profantová, Nad'a. Kultura s keramikou pražského typu a problém šíření slavinity do střední Evropy. K článku Florina Curty // Archeologické rozhledy. 2009. Vol. 61. S. 303-330.

Puschner, Uwe. Germanenideologie und völkische Weltanschauung // Zur Geschichte der Gleichung «germanisch-deutsch» / Hrsg. von Heinrich Beck, Dieter Geuenrich, Heiko Steuer, Dietrich Hakelbach. Berlin; New York: Walter de Gruyter, 2004. S. 103-129.

Riedinger, Rudolf. Pseudo-Kaisarios: Überlieferungsgeschichte und Verfasserfrage. München: C. H. Beck, 1969. $471 \mathrm{~s}$.

Rospond, Stanisław. Struktura pierwotnych etnonimów słowiańskich // Rocznik slawistyczny. 1966. T. 26. Nr 1. S. 31-32.

Schramm, Gottfried. Ein Damm bricht. Die römische Donaugrenze und die Invasionen des 5.-7. Jahrhunderts im Lichte von Namen und Wörter. München: R. Oldenbourg, 1997. 400 s.

Schramm, Gottfried. Venedi, Antes, Sclaveni, Sclavi. Frühe Sammelbezeichnungen für slawische Stämme und ihre geschichtlicher Hintergrund // Jahrbücher für Geschichte Osteuropas. 1995. Bd 43. Nr 2. S. 161-200.

Sławski, Feliks. Słowianie // Słownik starożytności słowiańskich. T. 5: S-Ś / Red. Gerard Labuda, Zdisław Stieber. Wrocław; Warszawa; Kraków; Gdańsk: Ossolineum, 1975. S. 274.

Smith, David Anthony. Myths and memories of the nation. Oxford: Oxford University Press, 1999. 288 p. Stanislav, Ján. Slovienin — Slovan — Slovák — Tót // Náš národ. 1944. Nr 1. S. 25-32.

Steinacher, Roland. Wenden, Slawen, Vandalen. Eine frühmittelalterische pseudologische Gleichzetung und Ihre achwirkungen bis ins 18. Jahrhundert // Die Suche nach den Ursprüngen. Von der Bedeutung des frühen Mittelalters / Hrsg. Von Walter Pohl. Wien: Verlag der Österreichischen Akademie der Wissenschaften, 2004. S. 329-353.

Surowiecki, Wawrzyniec. Śledzenie początku narodów słowiańskich. Wydanie fototypiczne. Wrocław; Warszawa; Kraków: Zakład narodowy imięnia Ossolińskich Wydawnictwo PAN, 1964. $201 \mathrm{s.}$

Surowiecki, Wawrzyniec. Z. D. Chodakowskiego O Słowiańsczyznie przed chrześciaństwem i W. Surowieckiego zdanie o pismie témźe z dodaniem krótkiej wiadomości o Chodakowskim i korrespondencyi jego. Kraków: Wydanie Antona Zygmunta Helcla, 1835. 51 s.

Schachmatov, Aleksei A. Zu den ältesten slavisch-keltisch Beziehungen (Herrn Akademiker Th. Korsch gewidmet) // Sonderabdruck aus Archiv für slavische Philologie. 1911. Bd 33. Nr 1/2. S. 51-99.

Šafárik, Pavol Jozef. Dejiny slovanského jazyka a literatúry všetkých nárečí. Bratislava: Vydavatel’stvo SAV, 1953. $601 \mathrm{~s}$.

Šafárik, Pavol Jozef. Slowanské starožitnosti. Oddjl Děgepisný. Praha: Pomocj Českého Museum, 1837. $1005 \mathrm{~s}$.

Schlözer, August Ludwig. Nestor Kiovensis 1056-1114: Russische Annalen in ihrer slavonischen GrundSprache. Göttingen: bei Heinrich Dieterich, 1802.340 s.

Téra, Michal. Slovanská identita v raném středoveku // Slovanství ve středoevropském prostoru. Iluze, deziluze a realita / Red. Dominik Hrodek et al. Praha: Libri, 2004. S. 53-60.

Třeštík, Dušan. Příchod prvních Slovanů do českých zemí v letech 510-535 // Český časopis historický. 1996. Roč. 94. Č. 2. S. 245-280.

Tyszkiewicz, Lech. Słowianie w historiografii antycznej do połowy VI wieku. Wrocław: Wydawnictwo Uniwersytetu Wrocławskiego, 1990. 218 s.

Verešová Nora. Vývoj chápania geografického termínu Sklavínia v historických prameňoch 6.-14. storočia // Historický zborník. Martin: Matica slovenská, 2008. Č. 1. S. 124-143.

Verešová $N$. Povest' vremennych let a jej koncepcia Slovienskoj zemli // Historia Nova. Vol. II: Štúdie k jubileu Pavla Jozefa Šafárika. Bratislava, 2011. S. 12-20.

Wenskus, Reinhard. Stammesbildung und Verfassung. Die Werden der frühmittelalterlichen gentes. Köln: Böhlau Verlag, 1961. $656 \mathrm{~s}$.

Živkovič, Tibor. De conversione Croatorum et Serborum. A lost source. Belgrade: Institute of History, 2012. $255 \mathrm{p}$. 


\section{Information about the article}

Author: Mesiarkin, Adam — Ph. D. in History, Assistant Professor, Institute of Social Medicine and Medical Ethics, Faculty of Medicine, Comenius University in Bratislava, Slovakia, adam.mesiarkin@fmed.uniba.sk Title: The name of the Slavs: etymology and meaning

Summary: The name is the main constitutive element and the most important identification sign of a barbaric community. The fixation of the name $\Sigma \kappa \lambda \alpha \beta \eta v o$ in the 6th century by Procopius of Caesarea and Jordanes as a designation of one of the groups of the trans-Danubian Barbaricum is the chronological boundary that separates the Slavs of prehistoric times from the historic Slavs. For a long time it was believed in historiography that the Slavs as a «people» or «cultural community» existed long before the 6th century, thus hiding in sources under other names. Of these names, the most important was the name Venethi / Venedi. However, the Slavs became Venethi, as well as the Venethi became Slavs, only thanks to Jordanes. The author of the article tends to the opinion that the name $\Sigma \kappa \lambda \alpha \beta \eta v o i ́$ was originally a designation of only one barbaric group, and then, due to various intellectual and ideological factors, it was transferred to other communities until it acquired the meaning in which it is understood today. Linguists, as well as historians, based on linguistic facts, a priori interpreted the self-name of the Slavs as based on the common language - on the word *slovo. It followed from this that this ethnic community arose on the basis of the language community. The thesis about the Slavs as «clearly speaking», that is, about the existence of an ethnic group, whose members determined themeselves through a common language already in the 6th century or even earlier, still occupies a strong position in Slavic studies. However, according to the author of the article, the picture according to which the formation of the group name «Slavs» was a result of the members of this group rational awareness that they use the unique «Slavic language» is not convincing. The connection between the name of the Slavonic community and the (Slavonic language) basis *slovo as well as the perception of the Slavs as the «people of the word» emerged much later: the linguistic interpretation of the ethnonym Slavs is the core of the intellectual and religious concept that took shape in the second half of the 9th century, being connected with the mission of Saints Cyril and Methodius in Moravia and Pannonia. For this reason, the author of the article prefers the etymology of the name «Slavs» proposed by the Polish linguist Zbigniew Babik because, in the author's opinion, it is Babik's etymology, and not the traditional linguistic view that reflects the reality of the Barbaric world of the early Middle Ages in more adequate way.

Keywords: ethnonym of Slavs, Slavic identity, Slavic ethnogenesis, Sclavi, slovene

\section{References}

Babik, Zbigniew. Współnota językowa prasłowiańska [Proto-Slavic language community], in Tabaczyński, Stanisław; Marciniak, Arkadiusz; Cyngot, Dorota; Zalewska, Anna (eds). Przeszłość społeczna. Próba konceptualizacji [Social past. An attempt of conceptualization]. Poznań: Wydawnictwo Poznańskie Publ., 2012. P. 838-851 (in Polish).

Bačić, Jakov. The Slav: Origin and the meaning of the ethnonym, in Slovene Studies. 1987. Vol. 9. No. 1/2. P. 33-41.

Barišić, Franjo. Kada su i gde su napisali Pseudo-Cezarijevi Dijalozi [When and where were PseudoCesarius' Dialogues written], in Zbornik radova Vizantološkog instituta. 1952. Vol. 1. P. 29-51 (in Serbian). Barford, Paul. The Early Slavs. London: British Museum Press, 2001. 416 p.

Benedicty, Robert. Prokopios' Berichte über die slavische Vorzeit. Beiträge zur historiographischen Methode des Prokopios von Kaisareia [Procopius' accounts on the Slavic past. A study of Procopius' of Caesarea historiographical method], in Jahrbuch der Österreichischen Byzantinischen Gesselschaft. Graz; Köln: Hermann Böhlaus Publ., 1965. Vol. 14. P. 61 (in German).

Bielowski, August. Wstęp krytyczny do dziejów Polski [Critical introduction to Polish history]. Lwów: Włodzimierz Hr. Dzieduszycki Publ., 1850. 542 p. (in Polish).

Brückner, Aleksander. Dzieje kultury polskiej. T. 1: Od czasów przedhistorycznych do r. 1506 [History of Polish culture. Vol. I: From prehistory to 1506]. Kraków: Krakowska Spółka Wydawnicza Publ., 1930. 58 p. (in Polish).

Curta, Florin. The making of the Slavs. History and archaeology of the Lower Danube Region, c. 500-700. Cambridge: Cambridge University Press, 2001. 436 p.

Curta, Florin. Sclaviniai and ethnic adjectives: A clarification, in Byzantion Nea Hellás. 2011. Vol. 30. P. 77-89.

Curta, Florin. Theophylact Simocatta revisited. A response to Andreas Gkoutzioukostas, in Byzantion Nea Hellás. 2016. Vol. 35. P. 195-209. 
Dzino, Danijel. Becoming Slav, Becoming Croat. Identity transformations in Post-Roman and early medieval Dalmatia. Leiden; Boston: Brill, 2010. 271 p.

Fusek, Gabriel; Zábojník Jozef. Príspevok do diskusie o počiatkoch slovanského osídlenia Slovenska [A contribution to the discussion on the beginning of the Slavic settling in Slovakia], in Slovenská archeológia. 2003. Vol. 51. No. 2. P. 319-340 (in Slovak).

Gołąb, Zbigniew. Veneti / Venedi. The Oldest Name of the Slavs, in Journal of Indo-European Studies. 1975. Vol. 3. P. 321-326.

Havlík Lubomír. Osídlení Balkánu Slovany a byzantská historiografie [The Slavs' settlement in the Balkans and the Byzantine historiography], in Pražák, Richard; Dorovský, Ivan (eds.). Studia Balcanica Bohemoslovaca. Brno: Universita J. E. Purkyně Publ., 1970. P. 48-58 (in Czech).

Havlík Lubomír. Počátky slovanského vědomí [Beginnings of the Slavic self-consciousness], in Št’astný, Vladislav (ed.). Slovanství v národním životě Čechů a Slováků [Slavdom in the national life of the Czechs and Slovaks]. Praha: Melantrich Publ., 1968. P. 17-23 (in Czech).

Homza, Martin. Stredná Európa I. Na začiatku stredoveku [Central Europe I. At the beginning of the Middle Ages]. Bratislava: Comenius University Publ., 2014. 313 p. (in Slovak).

Homza, Martin. Niekol'ko poznámok k básni Proglas [A few comments to the poem Proglas], in Homza, Martin; Mesiarkin, Adam (eds). Symboly a mýty národov v stredoveku a včasnom novoveku [Symbols and myths of peoples in the Middle Ages and early Modern Time]. Bratislava: Comenius University Publ., 2014. P. 13-24 (in Slovak).

Katičić, Radoslav. Die Ethnogenesen in Avaria [Ethnogenesis in Avaria], in Wolfram, Herwig; Pohl, Walter (eds). Typen der Ethnogenese unter besonderer Berücksichtung der Bayern [Types of ethnogenesis, with particular regard to Bavaria]. Vol. 1. Wien: Austrian Academy of Sciences Publ., 1990. P. 125-128 (in German).

Kolendo, Jerzy. Wenetowie a Słowianie [Venets and Slavs], in Z Otchłani Wieków: Pismo poświęcone pradziejom Polski [From remote ages: Journal devoted to the prehistory of Poland]. 1985. Vol. 51. No. 3-4. P. 125-130 (in Polish).

Krahwinkler Harald. Augewählte Slaven-Ethnonyme und ihre historische Deutung [Selected Slavic ethnonyms and their historical interpretation], in Bratož, Rajko (ed.). Slovenija in sosednje dežele med antiko in karolinško dobo. Začetki slovenske etnogeneze [Slovenia and neighbouring countries from the antique to Carolingian epoch. The beginning of the Slovenian ethnogenesis]. Ljubljana: National Museum of Slovenia Publ., 2000. P. 403-423 (in German).

Králik Luubor. Stručný etymologický slovnik slovenčiny [Scientific etymological dictionary of the Slovak language]. Bratislava: VEDA Publ., 2015. 704 p. (in Slovak).

Kučera, Matúšs. Slovenské dejiny I. Od príchodu Slovanov do roku 1526 [Slovakian history I. From the arrival of the Slavs to the year 1526]. Prešov: Michala Vašek Publ., 2008. 358 p. (in Slovak).

Labuda, Gerard. Fragmenty dziejów Stowiańszczyzny zachodniej, 1 [Fragments of the history of the Western Slavs, 1]. Poznań: Wydawnictwo Poznańskie Publ., 1960. 312 p. (in Polish).

Labuda, Gerard. Udział Wenetów w etnogenezie Słowian [Participation of the Veneti in the Slavic ethnogenesis], in Kwilecka, Irena (ed.). Etnogeneza i topogeneza Stowian: Materiaty z konferencji naukowej zorganizowanej przez Komisje Slawistyczna przy Oddziale PAN w Poznaniu w dniach 8-9 XII 1978 [Ethnogenesis and topogenesis of the Slavs. Materials from a scientific conference organized by the Slavic Commission of the Poznan branch of the Polish Academy of Sciences, 8-9. XII. 1978]. Warszawa; Poznań: Państwowe Wydawnictwo Naukowe Publ., 1980. P. 29-41 (in Polish).

Lysý, Miroslav. Moravania, Mojmírovci a Franská ríša. Štúdie k etnogenéze, politickým inštitúcim a ústavnému zriadeniu na území Slovenska vo včasnom stredoveku [Moravians, Moimir dynasty, and the Frankish empire. Studies on ethnogenesis, political institutions, and power system in the territory of Slovakia in the early Middle Ages]. Bratislava: Atticum Publ., 2014. 374 p. (in Slovak).

Malinovská, Nora. Geographical concepts of Sclavinia in historical sources from the sixth to the fourteenth century, with an emphasis on the Moravian-Pannonian and South Slavic tradition, in Homza, Martin; Lukačka, Ján; Budak, Neven; Kucharská, Veronika; Kuzmová, Stanislava; Mesiarkin, Adam (eds). Slovakia and Croatia. Historical parallels and connections (until 1780). Bratislava; Zagreb: Department of Slovak history, Faculty of Philosophy of the Comenius University, Bratislava; Faculty of Philosophy of Zagreb University, 2013. P. 60-65.

Margetić, Lujo. Etnogeneza Slavena [Ethnogenesis of the Slavs], in Rad Hrvatske akademije znanosti i umjetnosti. 2005. Vol. 492. P. 91-143 (in Croatian). 
Marsina, Richard. F. V. Sasinek: Dejepis Slovákov (Ružomberok 1895) [F. V. Sasinek: History of the Slovaks (Ružomberok 1895)], in Mulík, Peter (ed.). Čo písal o našich dejinách Franko Sasinek [What did Franko Sasinek write on our history]. Martin: Matica Slovenská Publ., 2015. P. 11-39 (in Slovak).

Miklosich, Franz. Altslovenische Formenlehre in Paradigme. Texten aus Glagolitischen Quellen [OldSlavic formations in paradigme. Texts from Glagolitic sources]. Wien: Wilhelm Braumüller Publ., 96 p. (in German).

Moszyński, Kazimierz. Pierwotny zasiag języka prasłowiańskiego [Original scope of the Proto-Slavic language]. Wrocław; Kraków: Zakład Narodowy im. Ossolińskich Publ., 1957. 332 p. (in Polish).

Moszyński, Leszek. Czy Słowianie to rzeczywiście nomen originis? [Is the name of Slavs indeed a nomen originis?], in Z polskich studiów slawistycznych. Seria 5: Językoznawstwo. Prace na VIII. międzynarodowy kongres slawistów w Zagrebiu 1978 [From Polish studies in slavistics. Series 5: Linguistics. Proceedings of VIII International Slavic Congress in Zagreb in 1978]. Warszawa: Państwowe Wydawnictwo Naukowe Publ., 1978. P. 497-507 (in Polish).

Mulík, Peter. Používanie kl’účových termínov k počiatkom slovenských dejín [Use of key terms for the beginning of the Slovak history], in Etnogenéza Slovákov. Kto sme a aké je naše meno [Ethnogenesis of the Slovaks. Who we are and what is our name]. Martin: Matica Slovenská Publ., 2011. P. 39-53 (in Slovak).

Nalepa, Jerzy. O pierwotnych siedzibach Słowian w świetle nowszych badań archeologicznych, lingwistycznych i historycznych [On the first settlements of the Slavs in the light of current archaeological, linguistical, and historical studies], in Slavia Antiqua. Vol. 48. 2007. P. 11-46 (in Polish).

Niederle, Lubor. Slovanské starožitnosti. Díl 2. Svazek 1. Původ a počátky Slovanů jižních [Slavic antiquites. Part 2. Vol. 1. The origin and beginnings of Southern Slavs]. Praha: Bursík and Kohout Publ., 1906. 547 p. (in Czech).

Ondruš, Šimon. Pôvod etnonyma Slovák, Slovan, Slověn a etnonyma Čech [Origin of the ethnonym Slovák, Slovan, Slověn, and the ethnonym Czech], in Studia Academica Slovaca. Prednášky XI. letného seminára slovenského jazyka a kultúry [Studia Academica Slovaca. Lectures of the 11th summer seminar of the Slovak language and culture]. 1975. Vol. 4. P. 223-241 (in Slovak).

Ossoliński, Józef Maksymilian. Wiadomości historyczno-krytyczne do dziejów literatury polskiey: O pisarzach polskich, także postronnych, którzy w Polscze albo o Polscze pisali, oraz o ich dziełach; z rozstrząśnieniem wzrostu i różnéy kolei ogólnego oświecenia, jako też szczególnych nauk w Narodzie Polskim. T. 1 [Historical-critical news on the history of Polish literature: About Polish writers, including those who have written in Polish or about Polish, and about their works; With the ragged growth and various turns of general enlightenment, as well as special teachings in the Polish nation. Vol. 1]. Kraków, s. n., 1819. 507 p. (in Polish).

Otrębski, Jan. Słowianie. Rozwiazanie odwiecznej zagadki ich nazw [Slavs. A solution to the eternal mystery of their names]. Poznań: Księgarnia ziem zachodnich Publ., 1947, 191 p. (in Polish).

Panzer, Baldur. Quellen zur slavischen Ethnogenese. Fakten, Mythen und Legenden (Originaltexte mit Übersetzungen, Erläuterungen und Kommentaren) [Primary sources on the Slavic ethnogenesis. Facts, myths, and legends (Original texts with translations, explanations and commentaries)]. Frankfurt am Main: Peter Lang Publ., 2002. P. 15-19 (in German).

Peisker, Jan. Die älteren Beziehungen der Slawen zu Turkotataren und Germanen und ihre sozialgeschichtliche Bedeutung [Ancient relations of the Slavs with the Turkic-Tatar peoples and their social-historical significance]. Stuttgart: W. Kohlhammer Publ., 1905. 243 p. (in German).

Peisker, Jan. The expansion of the Slavs, in The Cambridge Medieval History. Vol. 2. Cambridge: Cambridge University Press, 1914. P. 418-458.

Podolan, Peter. Sláwa Bohyně a původ gména Slaůw čili Slawjanůw... Jána Kollára [Jan Kollar’s work «The Goddess Fame / Glory (Slawa) and origin of the name Slaw or Slawian...»], in Historia Nova. Bratislava: Stimul Publ., 2013. Vol. VI. P. 82-93 (in Slovak).

Pohl, Walter. Die Awaren: Ein Steppenvolk in Mitteleuropa, 567-822 n. Chr. [The Avars: A steppe people in Central Europe, 567-822 A. D.]. München: Beck Publ., 1988. 553 p. (in German).

Pohl, Walter. Die Germanen [Germanic peoples]. München: Oldenbourg Publ., 2000. 156 p. (in German). Pohl, Walter. Ein Jahrtausend der Wanderungen, 500-1500 [Thousand years of migrations], in Kaser, Karl (ed.). Kontinuitäten und Brüche: Lebensformen - Alteingesessene - Zuwanderer von 500 bis 1500 [Continuities and Breaks: Forms of life, established populations, migrants from 500 to 1500]. Klagenfurt: Wieser Publ., 2010. P. 150-159 (in German). 
Pohl, Walter. Telling the difference. Signs of ethnic identity, in Pohl, Walter; Reimitz, Helmut (eds). Strategies of Distinction. The construction of ethnic identities, 300-800. Leiden; Boston; Köln: Brill Academic Publ., 1998. P. 17-71.

Popowska-Taborska, Hanna. Utrwalone w języku ślady etnicznej wspólnoty Słowian [Traces of the Slavic ethnic community fixed in the language], in $Z$ językowych dziejów Stowiańszczyny [From the language history of Slavdom]. Warszawa: Slawistyczny Ośrodek Wydawniczy Publ., 2004. P. 161-166 (in Polish).

Pritsak, Omeljan. The Slavs and the Avars, in Settimane di studio del centro italiano di studi sull'alto medioevo. Vol. XXX: Gli Slavi occidentali e meridionali nell'alto medioevo [Week studies of the Italian center for early medieval studies. Vol. XXX: Western and Southern Slavs in the early Middle Ages]. Spoleto, 1983. P. 353-435.

Profantová, Nad’a. Kultura s keramikou pražského typu a problém šíření slavinity do střední Evropy. K článku Florina Curty [The Prague-type pottery culture and the problem of diffusion of Slavinity into central Europe. On the article by Florin Curta], in Archeologické rozhledy. 2009. Vol. 61. P. 303-330 (in Czech).

Puschner, Uwe. Germanenideologie und völkische Weltanschauung [German ideology and nationalistic imagination], in Beck, Heinrich; Geuenrich, Dieter; Steuer, Heiko; Hakelbach, Dietrich (eds.). Zur Geschichte der Gleichung "germanisch-deutsch» [On the history of the identification «Germanic-German»]. Berlin; New York: Walter de Gruyter Publ., 2004. P. 103-129 (in German).

Riedinger, Rudolf. Pseudo-Kaisarios: Überlieferungsgeschichte und Verfasserfrage [PseudoCaesarius: The history of tradition and the question of authorship]. München: C. H. Beck Publ., 1969. 471 p. (in German).

Rospond, Stanisław. Struktura pierwotnych etnonimów słowiańskich [Structure of the first Slavic ethnonyms], in Rocznik slawistyczny. 1966. Vol. 26. No. 1. P. 31-32 (in Polish).

Schramm, Gottfried. Ein Damm bricht. Die römische Donaugrenze und die Invasionen des 5.-7. Jahrhunderts im Lichte von Namen und Wörter [A dam breaks: The Roman Danube frontier and the invasions of the $5^{\text {th }}-7^{\text {th }}$ centuries in the light of names and words]. München: R. Oldenbourg Publ., 1997. 400 p. (in German). Schramm, Gottfried. Venedi, Antes, Sclaveni, Sclavi. Frühe Sammelbezeichnungen für slawische Stämme und ihre geschichtlicher Hintergrund [Venedi, Antes, Sclaveni, Sclavi. Early collective names for Slavic tribes and their historical background], in Jahrbücher für Geschichte Osteuropas. 1995. Vol. 43. No. 2. P. 161-200 (in German).

Sławski, Feliks. Słowianie [Slavs], in Labuda, Gerard; Stieber, Zdisław (eds). Słownik starożytności słowiańskich [Encyclopedia of Slavic antiquites]. Vol. 5: S-Ś. Wrocław; Warszawa; Kraków; Gdańsk: Ossolineum Publ., 1975. P. 274 (in Polish).

Smith, David Anthony. Myths and memories of the nation. Oxford: Oxford University Press, 1999. 288 p. Stanislav, Ján. Slovienin — Slovan — Slovák — Tót, in Náš národ. 1944. No. 1. P. 25-32 (in Slovak).

Steinacher, Roland. Wenden, Slawen, Vandalen. Eine frühmittelalterlische pseudologische Gleichzetung und Ihre achwirkungen bis ins 18. Jahrhundert [Wends, Slavs, Vandals. An early medieval pseudo-logical identifications and its effects until the $18^{\text {th }}$ century], in Pohl, Walter (ed.). Die Suche nach den Ursprüngen. Von der Bedeutung des frühen Mittelalters [The search for the origins. Of the importance of the early Middle Ages]. Wien: Austrian Academy of Sciences Publ., 2004. P. 329-353 (in German).

Surowiecki, Wawrzyniec. Śledzenie początku narodów stowiańskich [Study of the origins of Slavic peoples]. Wrocław; Warszawa; Kraków: Zakład narodowy imięnia Ossolińskich, Polish academy of sciences Publ., 1964. 201 p. (in Polish).

Surowiecki, Wawrzyniec. Z. D. Chodakowskiego O Stowiańsczyznie przed chrześciaństwem $i$ $W$. Surowieckiego zdanie o pismie témźe z dodaniem krótkiej wiadomości o Chodakowskim i korrespondencyi jego [Z. D. Chodakowski's "On the Slavdom before Christianity» and W. Surowiecki's opinion on this work with the addition of a short information on Chodakowski and his correspondence]. Kraków: Anton Zygmunt Helcl Publ., 1835. 51 p. (in Polish).

Schachmatov, Aleksei Aleksandrovich. Zu den ältesten slavisch-keltisch Beziehungen [On the oldest SlavicCeltic relations], in Archiv für slavische Philologie. 1911. Vol. 33. No. 1/2. P. 51-99 (in German).

Šafárik, Pavol Jozef. Dejiny slovanského jazyka a literatúry všstkých náreči [History of the Slavic language and literature of all the dialects]. Bratislava: Slovak academy of sciences Publ., 1953. 601 p. (in Slovak). 
Šafárik, Pavol Jozef. Slowanské starožitnosti. Oddjl Děgepisný [Slavic antiquities. Historical part]. Praha: Česky Museum Publ., 1837. 1005 p. (in Czech).

Schlözer, August Ludwig. Nestor Kiovensis 1056-1114: Russische Annalen in ihrer slavonischen GrundSprache [Nestor of Kiev (1056-1114): Russian annals and their original Slavic language]. Göttingen: Heinrich Dieterich Publ., 1802. 340 p. (in German).

Téra, Michal. Slovanská identita v raném středoveku [Slavic identity in the early Middle Ages], in Hrodek, Dominik; et al. (eds). Slovanstvi ve středoevropském prostoru. Iluze, deziluze a realita [Slavs in Central European space. Illusions, disillusionments, and reality]. Praha: Libri Publ., 2004. P. 53-60 (in Czech).

Třeštík, Dušan. Př́íchod prvních Slovanů do českých zemí v letech 510-535 [Arrival of the first Slavs to Czech lands in 510-535], in Český časopis historický. 1996. Vol. 94. No. 2. P. 245-280 (in Czech). Tyszkiewicz, Lech. Stowianie w historiografii antycznej do połowy VI wieku [Slavs in antique historiography before the mid-6th century]. Wrocław: University of Wrocław Publ., 1990. 218 p. (in Polish).

Verešová, Nora. Vývoj chápania geografického termínu Sklavínia v historických prameňoch 6.-14. storočia [Evolution of the notion of the geographical term Sclavinia in the 6th to 14th century sources], in Historický zborník. Martin: Matica slovenská Publ., 2008. No. 1. P. 124-143 (in Slovak).

Verešová, Nora. Povest' vremennych let a jej koncepcia Slovienskoj zemli [The Tale of Bygone Years and its concept of the slavic land], in Historia Nova. Vol. II: Štúdie k jubileu Pavla Jozefa Šafárika [Studies on the occasion of the anniversary of Pavol Jozef Šafárik]. Bratislava, 2011. P. 12-20 (in Slovak).

Wenskus, Reinhard. Stammesbildung und Verfassung. Das Werden der frühmittelalterlichen gentes [Tribal formation and political organization. The making of early medieval gentes]. Köln; Graz: Böhlau Verlag, 1961. 656 p. (in German).

Živkovič, Tibor. De conversione Croatorum et Serborum. A lost source. Belgrade: Institute of History Publ., 2012. $255 \mathrm{p}$. 